Crossing: The INPR Journal

\title{
A Caputian Reading of David Newheiser's Hope in a Secular Age
}

\section{Calvin Ullrich}

Published on: Nov 18, 2020

DOI: $10.21428 / 8766 \mathrm{eb} 43.07 \mathrm{ca} 0 \mathrm{~b} 01$

License: Creative Commons Attribution 4.0 International License (CC-BY 4.0). 


\section{Crossing: The INPR Journal}

Vol. 1 (2020): 198-206

DOI: $\underline{10.21428 / 8766 \mathrm{eb} 43.07 \mathrm{caOb01}}$

A Caputian Reading of David Newheiser's Hope in a Secular Age

Calvin Ullrich

Ecumenical Institute

Ruhr-Universität Bochum

ullrich.calvin@g.gmail.com

Now more than ever our experience of politics and faith is marked by a feeling of loss and 'disappointment.' At the time of writing, the world as we know it has been turned upside down and daily-life reconstituted. The deadly Corona virus, causing deaths now well over a hundred thousand globally, has brought entire nations to an economic stand-still and placed the livelihoods and wellbeing of many into precarity. Moreover, beyond the innumerable social, economic, and ecological ailments that already mark our contemporary condition, American cities (and now elsewhere) are pulsing with furious riots as violent clashes between police and protestors escalate against the backdrop of calls to end systemic racism. In the midst of this geopolitical watershed, religious institutions have equally found themselves vying for legitimacy. Members of faith communities are isolated from each other, unable to participate and share in collective activities and liturgical rites. Faith leaders struggle to pursue new digitally relevant ways of providing solace and comfort to those in desperate need. To finally make matters worse, presidents waive sacred texts in front of cameras for publicity, eerily reminiscent of fascist imaging from the early twentieth century. 
It is surely no overstatement that if in recent times we have ever needed a counter-narrative, what one might call a 'politics of hope', now is that time. This is what David Newheiser has given us in his prescient new book, Hope In A Secular Age (2019). Newheiser enjoins us that despite all the disappointment and uncertainty, we must persist; neither blindly into idealist utopias which resist ambiguity, nor into cynicisms which thwart concrete improvements. Hope as the solution to these false choices has that character of resilience which "enables desire to endure without denying vulnerability" (2). However, it is also a weighted concept rich in its Judeo-Christian resonances that are unmistakable in our 'secular' European languages (3). For Newheiser, the category of hope therefore offers a site for reflecting on the 'future of faith' in a 'secular age,' since it both draws from the religious archive and transcends secular rationality. The secular and religious poles enmeshing each other, and which structure the argument of the book, are the works of Jacques Derrida on the one hand, and the negative theological tradition represented by Dionysius the Areopagite on the other. Unlike the supposed epistemological certainty offered by modern reason or the triumphalism which sometimes characterizes Christian confidence (5-7), both thinkers share an 'affinity' between a religious and secular hope that is persistent but remains vulnerable to disappointment and uncertainty. Through these traditions Newheiser aims to clarify hope's character which he understands to be implicitly at work in Derrida's thought and Dionysius' negative theology. Without the ventriloquism characteristic of postmodern commentary, the welcomed lucidity of Newheiser's unadorned yet eloquent prose is matched by a tone that is balanced and measured but no less urgent with its intentions. An academic concinnity spans the book's six chapters, and is grounded in an impressive breadth of secondary sources and careful detail in the use of primary ones. From this Newheiser fashions an argument that convincingly retrieves the compatibility between Christian commitment and deconstruction. Beyond wanting to simply resurrect the old debates concerning the sympathies between these pre-and postmodern traditions, Newheiser's ultimate aim is to defend a non-dogmatic religious discourse what he calls a 'negative political theology' (132) - that is able to constructively contribute to political life in such a way that maintains its own self-critical awareness. This review will be structured in two parts. In the first I will outline the argument of the book's six chapter's, before limiting myself in the second part to some initial reflections that will critically consider Newheiser's interpretation of John D. Caputo.

In the first chapter Newheiser tacitly enters into the well-known debate in Derridian scholarship in terms of the 'definition of culture' and the place of 'theory' (or 'anti-theory') within it. In favour of the former - viz. deconstruction is not simply negation and critique - Newheiser argues for the continuous ethical implications of Derrida's thought from the early to late explicitly political works. Here, whether différance, justice or the democracy to-come, Derrida evinces a negativity that is not paranoiac, but reflexive to the extent that exposure to the Other opens up new possibilities for ways of being. In the space between criticism (negativity) and the need to continue speaking (affirmation) 
lies an 'ethics of uncertainty' which does not close down judgements, for example, but demands their continual revision. Such an ethics, therefore, "encourages a form of commitment that refuses complacency" and "exemplifies the discipline of hope, which presses forward despite its uncertainty" (19).

In the second chapter, Newheiser engages the negative theological tradition through the enigmatic sixth-century mystic, Dionysius the Areopagite. According to Dionysius, given the creator-creature distinction, no name for God, or indeed any predication of God is adequate for the divine. Hence, "because God is the creator of everything, one must affirm (kataphaskein) every name for God, but it is necessary to unsay (apophaskein) every divine name" (44). Similar to deconstruction, Newheiser boldly asserts that beyond the linguistic manoeuvres of apophatic discourse there are ethical and political implications to Dionysius' thought. Instead of being able to seize upon God as if s/he were some knowable object, Dionysius' apophatics requires a dispossession of the self in relation to God, which "becomes a means of ethical transformation" (47). An important hermeneutical question (and potentially problematic position for Newheiser's argument) are the implications of the ecclesial hierarchies in the Dionysian corpus that supposedly mediate the hidden knowledge of God. In response, Newheiser offers a compelling defence of the provisional nature of the ecclesial order; instead of creating an idol of the hidden God that is mediated through church hierarchy, this hiddenness becomes precisely a part of the apophatic tension in which the sacramental nature of the church, its symbols, and structures, are all relativized (57). Thus, "affirmation of the sacred enacts a disciplined critique that keeps both discourse and practice in motion" (60).

What the ethics (or apophatics) of uncertainty accomplishes is not merely an epistemological posture or 'discursive technique' of humility, but rather a 'discipline', 'practice' and 'commitment' of openness to what is unexpected (63). According to Newheiser, this "Discipline of Hope", which titles the third chapter, is for Derrida and Dionysius an activity that affirms the pursuit of a future - whether a democracy to-come or the kingdom of God - but does so with the understanding that this pursuit is always vulnerable to disappointment. Contrary to Albert Camus who thinks hope claims a false discomfort and imposes an artificial assurance denying the absurdity of existence (65), Newheiser argues that the vision of hope found in Dionysius and Derrida takes place on a 'groundlessness' that does not attempt to impose meaning on the world, but rather embraces the weight of life refusing to "circumscribe present uncertainty" (70). Since they have commitments which are 'different in content but not in kind,' as Newheiser repeats throughout the text, "the two authors share an uncertain hope they suggest that religious and secular hopes should not be opposed" (73).

The stakes of faith's 'future in a secular age' come to the foreground especially in the fourth chapter. A part of Newheiser's methodological argument is the performative dimension that emerges in the relationship between Dionysius and Derrida. If their affinity - operating on the level of ethics and not 
epistemology (86) - can hold, then this would not only clarify, but also justify the coherency of a faith that functions reliably within the context of secular modern pluralism. On Newheiser's reading, the relationship between negative theology and deconstruction has been misinterpreted through the presentation of an either/or scenario, replaying the philosophical dichotomy of form and content. Representative of the former is John D. Caputo who, according to Newheiser, insists that Derrida rejects negative theology in favour of a 'religion without religion' and thus without determinate content (85). Opposing this 'attenuated religiosity,' Jean-Luc Marion argues that Derrida is unfairly hostile toward negative theology, and that the latter should be defended because it presents us with a God already deconstructed (94). Drawing from previously unpublished material in Derrida's corpus (91), Newheiser's third-way approach argues that both Caputo and Marion over-determine the status of predicative statements in Derrida's interpretation of negative theology. By contrast, instead of having to choose between indeterminacy (Caputo) and determinate content (Marion), Newheiser says that both Derrida and Dionysius hold "affirmation and negation in tension" (86).

If Newheiser's alternate response to secularization includes the compatibility of deconstruction and negative theology, then the political implications of religion in secular politics can be demonstrated. This is the task for the final two chapters. In chapter five, "Atheism and the Future of Faith", he engages Mark Lilla's well-known attempt to disengage religion and politics for the sake of public life (113). Confirmed by the analyses of José Casanova and Talal Assad (118) which skilfully questions these assumptions, Newheiser argues that Derrida instead follows a "procedural secularism" that desires a neutral state but which permits the participation of religion in the public sphere (114). In the line of Carl Schmitt and drawing on Paul Kahn, modern political concepts are not just reactions to Christianity but still continue to function theologically. Following the formal indistinguishability between Derrida's political-religious faith and negative theology, Newheiser subsequently, and rightly, rejects Martin Hägglund's reading that Derrida himself dismisses religion in favour of a radical atheism (126). For Derrida, the fragility of political life should lead neither to the often-violent imposition of religion as a means for stabilizing instability, but nor should it be the reason that religion is relegated. On the contrary, "the reason religion is dangerous is the reason it is indispensable: it opens imagination to a future that has not yet come into view" (131).

Having crafted this opening for religion to present itself as a potentially positive force for political life, Newheiser introduces his own notion of a 'negative political theology'.[1] Returning to Dionysius, the latter's apophatics can now "contribute to democratic politics", wherein "political movements can affirm realistic proposals in hope while subjecting them, at the same time, to utopian critique" (132). The foil for Newheiser's argument in the final sixth chapter is Giorgio Agamben's reading of Dionysius, and reflects the same issue of hierarchy dealt with in chapter two, except now with the political implications in full view (134). In short, Agamben argues in The Kingdom and The Glory (2011) that Dionysian mysticism reinforces the ecclesial order (because the latter mediates the unknowable God) 
and therefore, according to Agamben's thesis, becomes a model of sacralization for the glorification of contemporary government bureaucracy (137). Opposing specialist readings that seem to confirm Agamben's intuitions, including Andrew Louth and Alexander Golitzin, Newheiser insists that Dionysian apophatics does not affirm the authority of Christian worship. Instead, "[r]ather than sacralizing the oikonomia of the church by associating it with the theologia of divine transcendence, Dionysius desacralizes every claim to access the divine" (140). As such, the apophatics of negative theology is in fact closer to achieving Agamben's political goals than he himself recognizes, since it both delimits theological authority and continues to proliferate speech about God-similar to what Agamben calls 'play' or 'profanation' (143). Dionysius therefore offers a negative political theology that stems assertions of power, but which also does not shy away from bold affirmations that are nevertheless always provisional.

In moving now to the second part, I would like to state at this point that I am deeply sympathetic to Newheiser's project, both in the broad sense with respect to the value of hope as arguably the politicalreligious category of our time, and more precisely to the creative way in which post-secular deployments of religious and philosophical resources are expedient for addressing contemporary political challenges. Newheiser's argument is, at its most fundamental level, concerned with maintaining the interdependence between affirmation and negation. Affirmation without negation leads to dogmatism, and negation without affirmation leads to cynicism. In the delicate maintenance of both resides a mutually productive tension wherein the phenomenon of hope is to be situated. For Newheiser, both Derrida (who tends to be more 'melancholic') and Dionysius (who seems more 'sanguine') are able to balance this tension wherein it is "neither necessary to avoid negativity in order to preserve the possibility of affirmation nor to avoid religious commitment in order to preserve the possibility of critique" (73). But for Newheiser there are some interpretations of Derrida in particular where the preservation of affirmation is lost in the amplification of negativity. John $\mathrm{D}$. Caputo's reading of Derrida according to Newheiser, takes this stance which descends into cynical despair, because a 'celebration of indeterminacy' hinders one's ability to make determinate decisions, articulate specific hopes, or offer concrete proposals. In my view, I do not think that this is an accurate rendering of Caputo's Derrida, and would go further to say that Newheiser's own position with some qualifications, ends up closer to Caputo than what he may have thought.

One important qualification is whether Newheiser's updated treatment of Derrida's relationship to negative theology is in fact accurate. For the reflections that follow, I would like to bracket this question because I readily concede that the picture here is more complex, and Newheiser's exceptional archival work seems to have confirmed this. However, if Caputo has contributed to the oppositional relationship between Derrida and negative theology, I do not believe, as Newheiser argues, that Caputo's interpretation of Derrida "hinges" (86) on it, nor do I think, therefore, that to emphasize the "messianic rather than apophatic" (87), as Caputo does, results in the dialectical reading of Derrida 
that simply undervalues 'determinate religion' or the concrete practices and decisions which necessarily involve daily life. On the contrary, I think that Newheiser's mistake with respect to Caputo is precisely to have limited his interpretation to the first chapter in Prayers and Tears. Here again a second qualification; even if Caputo has over-emphasized the role of superessentialism in negative theology (92), he cannot be said to only "sometimes acknowledge that messianism always takes a determinate form", as Newheiser quietly footnotes (74). Caputo, on my reading, is very well aware of these tensions in Derrida as well as in his own thought, and while it could be argued that there may indeed be some rhetorical slippage that occurs in some of his 'middle' period,[2] this cannot for the most part be said of his later work (which Newheiser does not engage).[3] My claim, then, would be that Caputo is not a counter-productive source for the project of a 'negative political theology', but rather, in virtue of what I would call his own 'radical political theology', he might, in fact, come to be considered a congenial ally.

Newheiser's position can be summarized as follows: "Derrida's emphasis on indeterminacy serves a specific function: it aims to disrupt the assurance that justice is already realized. At the same time, although the future is undecidable, Derrida acknowledges that undetermined openness is not a state that people can achieve" (75). The latter signals that 'indeterminacy' or 'openness' is not the Kantian regulative ideal toward which we asymptotically move - we cannot 'live' or 'dwell' in the undecidable, if that is to mean the avoidance of making decisions in the here-and-now. Caputo is charged with insisting "upon an indeterminacy that no one can actually sustain" (86). As mentioned, Newheiser's interpretation of Caputo is limited to the latter's reading of negative theology, and since this relationship in particular is primary for Newheiser's aims regarding Christian theology vis-à-vis deconstruction, he treats the argument here in isolation, misconstruing Caputo's overall depiction of Derrida as one that peddles "simplistic oppositions" (105). The cited text from Newheiser's footnote referred to above is actually the culmination of several carefully considered pages in Prayers and Tears [4] where Caputo intends 1) to emphatically resist the oppositional thinking Newheiser accuses him of and 2) to accentuate, not simply 'acknowledge,' the irreducible particularities of life, which is, moreover, central (the hinge?) to his understanding of deconstruction. Let me quote him at length here:

The messianic goes to the heart of deconstruction and of deconstruction's passion and deconstruction's religion, its affirmation of and engagement in the world, in events, in what is happening, in traditions and what is to come, in 'life/death,' survivnace, surviving today Derrida's desert-like and arid, ankhôral, atheological messianic enjoys a great deal of the life of the historical messianisms, of their historical hope, of their religious affirmation of something that is to come, a great deal of the energy of engagement.[ㅁ] 
Caputo quite clearly understands that deconstruction's messianic hope is not a purity, a 'true' messianic in general, or a sublime alterity, for that would strictly have the "form of absolute inhospitality, of uninhabitability."[6] One could grant some further allowances for the view that Caputo denigrates particular hopes if we continue to follow Newheiser's citation of passages from Caputo's popular autobiographical work Hoping Against Hope. But even amidst the lyrical prose of this text, the caricature of revelling indeterminacy remains imprecise, since Caputo consistently stresses that what he is trying to describe is something "going on in religion" - not something outside, spinning indeterminately.[7] Newheiser rightly points to a number of commentators who agree with him, citing essays by Jamie Smith, Kevin Hughes[]] and Arthur Bradley.[9]

In my reading, there is definitely a reception of Caputo's book that has had this effect, and subsequently many of these critics, if not all of them, have the same central concern: How to read the 'without' (ohne, sans) between religion and its double? Or inversely, what happens to the 'with' of religion, the determinate hopes that religion offers? Caputo had reflected at length and responded to many of these complaints already early on, [10] and he continues to refer supposedly new criticisms of his more theological texts, to these earlier essays. [11] In short, I think that Newheiser believes Caputo has embraced an understanding of Derrida that essentially reviews him as a postmodern Kantian. Religion without religion is akin to a 'religion within the limits of reason alone', which stands opposed to any determinate hopes that are made available through the revelation of the Christian faith. But in my reading, Caputo is explicit that the way to get beyond the Heideggerian distinction - to which Derrida refers as a 'temptation' in "Faith and Knowledge" and which I think Newheiser himself has fallen into, not Caputo - between 'revelation' and 'revealability,' is to introduce the famous quasitranscendental. In "Faith and Knowledge" this is encapsulated by the notion of foi. However, foi, that kind of archi-faith, if left by itself (a pure messianic indeterminacy) remains empty, and so should be understood "hauntologically" as that which 'haunts' the determinate faiths (croyances). Viewed in this way, Caputo does not believe that this archi-faith, or religion without religion, is a "faith that somebody believes, or a religion that somebody can inhabit." [12] Rather he understands this foi as "a ghost, a spectre, that haunts us in the sorts of concrete positions-philosophical, political and religious - that we do take." A religion without religion holds these commitments and these hopes to account, and renders them provisional as Newheiser might say.

As I have tried to argue elsewhere, alongside broader philosophical movements that have tried to reclaim the 'materiality' of deconstruction and phenomenology after the predominance of 'textuality', [1] $]$ as well as what could well be a reaction to this residual Kantianism discerned in Caputo's work, I think his later more explicit theological texts, which include a turn to Hegel, can be considered his definitive effort to quell these concerns over the status of 'matter', 'materiality' and historical 
instantiations of faith that have been raised by Newheiser and others. If I am correct to say that the picture Newheiser has presented of Caputo in Hope In A Secular Age cannot simply be reduced to an uninhabitable experience of indeterminacy, then I wonder how Newheiser might respond when Caputo now begins to embrace and speak of a 'radical theology' that seeks a "possibilizing" of the event, or which emphasizes the proximity of "existence and insistence," or the "becoming radical of confessional theology" in his more recent work (The Insistence of God, 2013 and Cross and Cosmos, 2019). In this light, a light that shares the productivity that is generated by Derrida's negativity, are Caputo and Newheiser in the end so different? Do they not have similar provisional hopes and dreams? Is Caputo not a source of misunderstanding, but rather a forceful ally for a world that desperately needs to learn how to hope? I think he might be, and lord knows, we all need the help and hope we can get in these troubled times.

[1] The term, however, is usually associated with Jacob Taubes, but see Newheiser's own "Why The World Needs Negative Political Theology" in Modern Theology 36 no. 1 (January, 2020): 5-12, where he further elaborates its history and distinguish his own intentions with the phrase.

[2] I think this is especially the case in Caputo's Against Ethics (1993). In my reading the rhetorical effect of that book is a negative anthropology that declares the ontological status of cosmic meaningless as a fact of the world, ultimately culminating in the inability to decide, which is the essence of Newheiser's complaint, as I understand it.

[3] I develop these stages in Caputo's work in greater detail in Sovereignty and Event: Toward John D. Caputo's Radical Political Theology (Tübingen, Mohr Siebeck: 2021 forthcoming).

[4] John D. Caputo, The Prayers and Tears of Jacques Derrida: Religion Without Religion (Indiana: Indiana University Press, 1997), 134-44. In these pages Caputo is in fact so careful about avoiding simplistic oppositions, that he is even concerned that Derrida himself may have framed the discussion between the messianic and the historical messianisms in too simplistic terms, 137-38.

[ㄷ] Ibid., 141-2.

[6] Ibid.

[7] John D. Caputo, Hoping Against Hope: Confessions of a Postmodern Pilgrim (Minneapolis: Fortress Press, 2015), 18. Before referring to the concrete work of religious 'sanctuaries', 'justice workers,' Pope Francis as the 'pope of the poor' (20) - all surely inspired by Christianity's determinate commitment to 
God's reigning Kingdom of justice - Caputo writes, "I will state from the start that these three-hope, the reality of the material world, and (an oddly religionless) religion-are my non-negotiables." (18). This hardly sounds like the 'celebration of indeterminacy' that Newheiser suggests.

[8] Both Smith and Hugh's essays appear in The Future of Hope: Christian Tradition amid Modernity and Postmodernity, edited by Miroslav Volf and William Katerberg (Grand Rapids, MI: Eerdmans, 2004).

[9] Arthur Bradley, "Without Negative Theology: Deconstruction and the Politics of Negative Theology," Heythrop Journal 42 no. 2 (2001).

[10] See John D. Caputo, "Hoping in hope, hoping against hope: a response" in James H. Olthuis (ed.) Religion With/Out Religion: The Prayers and Tears of John D. Caputo (London: Routledge, 2002), 120-149. The one criticism of Caputo's understanding of the 'without' in defense of the 'with', which he considers to be particularly sensitive was Kevin Hart's, "Without" in Marko Zlomislić and Neal DeRoo (eds.) Cross and Khôra: Deconstruction and Christianity in the Work of John D. Caputo (Eugene, OR: Wipf and Stock, 2010), 80-108 and Caputo's reply in the same volume "Only as Hauntology Is Religion without Religion Possible: A Response to Hart," 109-117.

[11] See more recently J. Aaron Simmons and Stephen Minister (eds.) Reexamining Deconstruction and Determinate Religion: Toward A Religion With Religion (Pittsburgh: Duquesne University Press, 2012). And Caputo's more than eighty-page response, "On Not Settling for an Abridged Postmodernism: Radical Hermeneutics as Radical Theology”, 271-353. In this essay Caputo refers repeated to his early work, which the authors of the volume seem not to have properly taken into account.

[12] Caputo, “Only as Hauntology Is Religion without Religion Possible," 114.

[13] For example, Richard Kearney and Brian Treanor's (ed.) Carnal Hermeneutics (New York: Fordham University Press, 2015). 